\title{
The Effect of Self-Regulated Learning and Tawakal (Trust in God's Plan) in Learning towards Students' Academic Stress
}

\author{
Nur Fatimah $^{1}$ and Lidya Freyani Hawadi ${ }^{2}$ \\ \{fatimahxdbs@gmail.com¹, akbarhawadi@gmail.com² \\ School of Strategic and Global Studies, University of Indonesia, Jalan Salemba Raya, Jakarta Pusat, \\ DKI Jakarta, Indonesia ${ }^{1}$, School of Strategic and Global Studies, University of Indonesia, Jalan Salemba \\ Raya, Jakarta Pusat, DKI Jakarta, Indonesia ${ }^{2}$
}

\begin{abstract}
Academic Stress has a negative influence on the learning process and student achievement. Among the efforts to reduce academic stress is by developing selfregulated learning, which is a behavior in which a person is able to manage his or her own learning process. On the other hand, in Islamic teachings an attitude called tawakal (trust in God's plan) is recommended for Muslims, which means to try and surrender to Allah. This attitude can be applied in various activities including learning, which are described with sincerity in learning and surrender to Allah after trying. The author in this study wanted to find out whether self-regulated learning and trust in learning had a significant effect on academic stress. By using quantitative methods, this study involved 150 active Muslim students at S1 level and equivalent to S1 (D4 and S1 extensions) in both public and private universities in Jakarta, Bogor, Depok, Tangerang and Bekasi. This study shows that self-regulated learning has a significant influence on academic stress. Tawakal in learning also has a significant effect on academic stress. Then selfregulated learning and tawakal in learning simultaneously proved to have results in academic stress on students.
\end{abstract}

Keywords: Academic Stress, Self-Regulated Learning, Tawakal in Learning.

\section{Introduction}

According to a study in 2015 conducted by the National College Health Assessment (NCHA), it was stated that $32.2 \%$ of students in the United States experienced stress during the past year which resulted in their academic achievements declined [1]. Then in the following year (2017), the stress level for students increased to $34.4 \%$. In Indonesia, students' academic stress levels vary greatly depending on the learning environment. Research on academic stress levels in Indonesia is still limited at the faculty or university level and there has been no national level research, so the researchers cannot include outline figures on academic stress levels in Indonesian students.

Academic stress among students brings in many negative influences including a decrease in academic achievement. Based on a brief interview with a number of final year undergraduate students, the academic stress they experience is mostly due to the lack of motivation in doing both their daily and final assignments or thesis. Some students feel they do not understand the learning material, which leads to reduced motivation for completing the 
task. In addition to not fully understanding the lecture material, in the writing of their thesis some students interviewed find it difficult to start. This is also influenced by a lack of understanding of the material and students' effort to seek the help from lecturers, friends or other more knowledgable people.

One effort in learning strategies and improving academic achievement is self-regulated learning, which involves the ability of students to be more metacognitive, motivated and actively participating in their own learning process [2]. A study shows a negative relationship between academic stress and self- regulated learning [3]. If self- regulated learning is improved, academic stress will decrease. Students with good self-regulated learning show good achievement and low academic stress levels. On the contrary, students with low selfregulated learning experience high academic stress so that academic achievement decreases.

As stated by Zimmerman and Martinez-Pons [2], self-regulated learning involves students' metacognitive abilities, their motivation and behavior in learning. So it can be said that self- regulated learning involves three factors. The first is metacognitive abilities, namely the knowledge and control students have about their own thinking and learning activities [4]. Examples of metacognitive abilities are that students with self- regulated learning are able to plan their own learning strategies appropriately. Then self-regulated learning also involves motivational factors in it, this motivation moves students to continue to be enthusiastic in the learning process. The next factor is behavior; students with self-regulated learning will try their best to practice and seek help from friends or lecturers to support their understanding of lecture material.

Then what happens in the field is when students experience stress, they are unable to use metacognitive abilities to plan the right learning strategies for themselves. Even though they have made a learning plan, those who experience academic stress are not able to carry out the learning strategies they have made before. Conversely, students who can get through the learning process in accordance with the plans they make and are strict in managing themselves in order to complete the study well, usually have low academic stress levels. This matches the previous studies, which proven that self- regulated learning has a negative correlation with academic stress, that is if self-regulated learning increases, academic stress will decrease. Vice versa, if self-regulated learning decreases and vice versa [3].

A study finds that spirituality in education can increase and stimulate awareness, foster creativity and imagination, connect someone with purpose and meaning and facilitate relations with God [5]. In Indonesia, education is an attempt to develop the potential of students to have religious spiritual power [6]. One of the spiritual levels in Islam is tawakal (trust in God), which provides individuals with calm attitudes in dealing with various problems and always try hard and surrender fully to Allah. Tranquility in the heart is a guarantee from God for those who trust, accompanied by effort.

Prof. Achmad Mubarok said that in Western psychology, the goal is to explain human behavior, predict and control it. Meanwhile in Islamic psychology, there are two other goals, namely to build good behavior and encourage people to get closer to God. Tawakal attitude in this case becomes one of the right attitudes to build good behavior and get closer to God. Tawakal in study has proven to have a negative correlation with academic stress [7]. This is the reason for juxtaposing tawakal variables in learning with self-regulated learning, these two variables have a negative correlation with stress so that researchers want to know more about whether tawakal in learning is affecting academic stress on students in such significant level.

Tawakal comes from the word wakala and is listed in the Qur'an 70 times [8]. One verse of the Qur'an which shows the command of tawakal is in Surah Al-Ahzab verse 3:

"And trust in Allah and Allah is sufficient as a keeper" 
The above verse shows the commandment of trust for man and that Allah guarantees a calm life for humans as long as he trusts Him (Ibn Katsir, n.d). Resignation or surrender to God is represented by striving to achieve goals and worship God and be sure of all decisions. Trying to the maximum before surrendering to God can lead to readiness in a person before facing an exam. This self-readiness is shown by being calm and accepting all decisions that will occur. If it is associated with life on campus, based on interviews with several students about tawakal attitudes when facing exams, they express their attitude of trust, namely by praying more and asking for ease and strength in facing the test.

Then another tawakal command is also found in the word of Allah Almighty in the Surah Al-Anfal verse 49:

"(Remember), when the hypocrites and those who are sick in their hearts say," They (the believers) are deceived by their religion", (Allah says). "Whoever put his trust in Allah, know that Allah is The Most Mighty and Wise."

The verse above contains the command of tawakal to Allah when the Muslims are confronted by the infidels who consider them (the Muslims) to be a small number and think they are able to defeat the Muslims easily. Even though Allah is the Most Mighty and the Wise, which means that Allah is invincible and always puts something in its place, namely to establish victory for the (Muslim) people who are trustworthy and entitled to win [9]. It can be concluded that by putting trust in Allah Almighty a Muslim does not need to feel anxious, worried and afraid because Allah Almighty will overcome any of the difficulties faced by those who trust.

Understanding tawakal does not stop at surrender to Allah swt but also accompanied by efforts or maximum effort [10]. Contrary to submission, tawakal requires effort first before surrendering to Allah SWT. If applied in the lives of students, they still have to make every effort to learn and then surrender to Allah SWT to receive any results from their learning efforts. Several studies in Indonesia about tawakal have been carried out, some of which are the construction of tawakal scale measuring instruments which are the development of the surrender to god scale [11] and other studies on expectations, trust and academic stress relations [7] which proves that tawakal has a negative correlation with academic stress. If tawakal increases, academic stress decreases, and vice versa. From this it can be concluded that tawakal has two dimensions in it, namely the business dimension and dimensions surrender to Allah SWT. The other conclusion is that tawakal correlates negatively with academic stress, i.e. if tawakal attitude is high, academic stress is low.

Based on the explanation above, the research questions can be formulated as follows:

1. Does self-regulated learning have a significant effect on academic stress on students?

2. Does tawakal (trust in God) in learning have a significant effect on academic stress on students?

3. Does self-regulated learning and tawakal in learning have a significant effect on academic stress on students?

To prove the hypothesis, an analysis of the three variables, namely academic stress, selfregulated learning and tawakal (trust) in learning was carried out by using an instrument in the form of a measure to be constructed in this study. The academic stress gauge will be constructed based on academic stress measures from Lakaev Academic Stress Response (LASR) [12] while the self-regulated learning measure will be constructed based on Zimmerman's [13] theory. Furthermore, tawakal measurement tools in learning are constructed based on learning theory and tawakal from the translation of the book Ta'lim Muta'allim by Syaik Az-Zarnuji [14]. 


\section{Literature Review}

\section{1 Academic Stress}

Defining Academic Stress. Academic stress is a type of stress triggered by academic burdens, in this case the academic burden is a stimulus and the body's reaction to dealing with it is a response. Examples such as exam scores for some people are the average value and prospects for entering the next level of education but for others the test scores are related to self-esteem, peers, family and decisions in academic life [15]. The point in general can be said that academic stress is the body's response to stimulus in the form of academic burden and other related factors.

Academic Stress Indicator. Based on the definition of academic stress, the body's response to stimulus is academic load and other related [15]. These body responses can be grouped into four indicators, namely affection, behavior, physiological and cognitive [12]. Affection is related to one's feelings or emotions, in this case the cognitive assessment process is substantial in the development and expression of emotions because emotions are the result of something anticipated, experienced or imagined by someone from a transaction of adaptation between organisms and the environment [16].

Measuring Academic Stress. The researchers adapted academic stress indicators from Lakaev [12] namely affective, behavioral, physiological and cognitive responses. Then the researcher compiled items in the form of statements tailored to the research subject, namely students and their stimulus, namely academic burden as shown by Kohn and Frazer [17] in their academic stress measurement tools. Measuring instruments that have been prepared and ready for testing in this study contain 19 items in the form of a questionnaire with a Likert scale which will be explained further in the next section.

\section{2 Self-Regulated Learning}

Defining Self-Regulated Learning. Self-regulated learning is a learning process in which a person can organize himself, which involves metacognitive aspects, motivation and active behavior in learning [13]. Self- regulated learning was born from a theory advocated by Albert Bandura, a Canadian psychologist who introduced social cognitive theory, he stated that cognitive, social and behavioral factors are very important in one's learning process. For example, the Bobo Doll experiment which is one of Bandura's famous experiments. The experiment produced different behaviors in each child who saw how bobo dolls were treated 18]. This shows that someone learns, gets knowledge, behavior and abilities through what he sees or observes.

Dimentions and Indicators of Self- Regulated Learning. In general, self-regulated learning has three dimensions consisting of metacognitive, motivational and behavioral [13]. This comes from the Bandura theory known as the reciprocal determinism model.

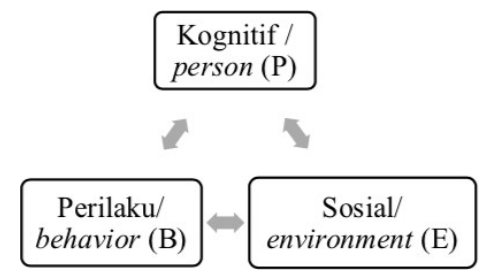

Figure 1. Reciprocal Determinism Model by Bandura 
Based on the model above, these three factors influence each other continuously so that everyone can learn. Environmental factors influence behavior, and vice versa behavior affects the environment. Then cognitive factors influence the environment and vice versa the environment also affects cognitive factors. Cognitive factors on the other hand also affect behavior and vice versa behavior affects one's.

In an analysis conducted by Zimmerman [13], it was stated that the learning process was not only influenced by personal (cognitive) factors but also influenced by environmental and behavioral factors. Self-regulated learning occurs when students can use their cognition to manage behavior strategically and directly affect their learning environment. A student can organize himself in the learning process by starting and managing their own efforts to gain knowledge and abilities rather than relying on the help of a teacher or parent or other people.

Three dimensions in self-regulated learning are metacognitive, motivational and behavioral [13]. The metacognitive dimension consists of several indicators or in measuring instruments in this study called indicators such as rehearsal, elaboration, organizing, goal setting, self- evaluating and monitoring.

Then the dimension of motivation consists of three indicators, namely self-efficacy, task value and internal attribution. Next is the dimension of behavior that refers to behavior during learning. In the behavioral dimension there are three indicators, namely effort regulation, environmental structuring (environmental regulation), and help seeking (search for help).

Measuring Self-Regulated Learning. The measuring instrument used in this study is a construction based on Zimmerman's theory of self- regulated learning which consists of dimensions of metacognition, motivation and behavior. The items in the measuring instrument are compiled by researchers based on Zimmerman's theory with adjustments to the subject of research namely students. After the items are compiled and tested for validity and reliability, then the measuring instrument is ready to be used in this study. The construction of a selfregulated learning measurement tool in this study will be explained in more detail in the next section

\section{3 Tawakal in Learning}

Defining Tawakal in Learning. Tawakal is an Arabic word derived from the word wakala which if pinned to the Name of Allah means to make Allah a representative or helper. As in a verse of the Quran it is written that Allah forbids His servants to take representatives or helpers other than Him (Al-Isra: 2), those who put their trust in Allah know that Allah is the one who provides all his sustenance and business until he is dependent on Allah only, not to others [19]. Tawakal to Allah means relying on or hanging on his business [20]. Tawakal, in the Arabic language, also means hanging on to others or showing weakness and dependence on others. Then in terms, tawakal has several definitions including believing in Allah and not wishing for humans [21].

Then tawakal, according to Al-Ghazali, is to rely only on representatives, namely Allah alone [22]. In essence tawakal is the heartedness of God by taking the causes (which bring people closer to their goals or human endeavors to achieve goals) which are accompanied by complete confidence in Allah that He Gives sustenance, Who Turns On and Who Revokes, there is no God but Allah [20]. The word wakala is listed in the Quran as much as 70 times [8] and is one of the main teachings in the Islamic religion.

In addition to surrender, another aspect found in tawakal is effort [10]. This aspect is important because in fact Allah SWT commands believers to always strive until finally Allah 
SWT will guarantee the best results in accordance with human effort. Allah SWT says in the Al-Quran Surah Ar-Ra'd verse 11.

The verse shows that Allah will not change a person's condition except on the basis of his own efforts to change things. So it is not right to say it is enough to surrender to Allah SWT without trying.

People who put their trust in Allah according to Prof. Dr. Quraysh Shihab means to appoint Allah Almighty as representative in all matters. Choosing Allah Almighty as a representative is of course different from choosing people as representatives. Allah Almighty with all his knowledge and power knows more about the benefit of humanity who lifts him as a representative, other than humans as representatives of other human beings whose knowledge is limited. So that the person who trusts has the belief that what he gets is the best plan from Allah SWT for him. Then another difference is that when someone appoints a human being as a representative, the representative is the one who works or tries. But when the person who trusts chooses God Almighty as a representative, then the person who trusts must try and work as hard as he can, after that surrender to Allah SWT. Therefore, there is no trust before trying or working [23]. From here the authors conclude that tawakal has two dimensions in it, namely the effort dimension and dimension of surrender to Allah swt.

Dimensions and Indicators of Tawakal in Learning. Based on the previous explanation, tawakal can be concluded to have two dimensions, namely the effort dimension and the surrender to Allah SWT dimension. The effort dimension in learning consists of several indicators including the intention to learn, tawadhu', choose knowledge, choose a teacher and study partner, be patient, diligent, earnest, grateful, pray and trust. Furthermore, the surrender dimension has indicators in the form of gratitude, prayer and trust in Allah SWT [15].

Measuring Tawakal in Learning. The construction of tawakal measuring instrument will be made based on tawakal theory by Syaikh Az-Zarnuji. The researcher also asked expert judgment in making dimensions, namely surrender dimension and effort dimension. From these dimensions, indicators will be made and indicators of statements about tawakal attitude in learning based on the book Ta'lim Muta'allim, tawakal in learning measuring instruments, and testing the validity and reliability.

\section{Research Methods}

This study uses a quantitative method in the form of research with primary data collection in the form of the results of participant questionnaires and secondary data in the form of results of previous studies, journal articles, news and survey results to support research data. Primary data obtained from respondents were then processed with SPSS 24 statistical software. This quantitative research was compiled based on the results of statistical analysis of primary data to determine the relationship and influence between variables.

This research begins with the construction of a scale or research instrument. The instrument used in this study is the scale of academic stress compiled by researchers based on Lakaev Academic Stress Response (LASR) [12], the scale of self-regulated learning compiled based on Zimmerman's theory [13] and scale of tawakal in learning theory from Syaikh AzZarnuji [14] in (translated) the book Ta'lim Muta'allim.

Once compiled, the scales are then tested for validity and reliability. The scale that passes the validity and reliability test is then compiled in a google form questionnaire form and is 
ready to be used in research by dissemination to the subject or participants of the study. The data obtained is in the form of answers to the scale that has been distributed. The data is then processed using SPSS 24 statistical software to answer the research hypothesis.

\section{1 Scale/Research Instrument Construction}

Scale for Academic Stress. The content of the academic stress questionnaire consists of items in the form of statements prepared by researchers based on the academic stress scale by Lakaev [12] which has four indicators namely affection, behavior, physiological and cognitive. The items in this questionnaire were also made by adjusting the research subject, namely the student and the stimulus, namely academic load. In addition, this questionnaire also consists of four choices of answers in each statement which are "really not suitable for me", "not suitable for me", "suitable for me" and "very suitable for me. After that, this academic stress scale trial was carried out to determine the validity and reliability of the scale.

To find out the validity of an instrument, respondents' answers to the trial questionnaire were analyzed by correlation test between scores and criteria. The criteria in this trial are divided into two, the first is the criteria of respondents with high academic stress and the second criterion is respondents with low academic stress. An item is said to be valid if it has a correlation value ( $r$ ) of at least 0.3 , items with a correlation value (r) below 0.3 are considered invalid and should be eliminated from the scale. Below is a table detailing the number of valid and invalid items on the academic stress scale:

Table 1. Number of Items on the Academic Stress Questionnaire Before \& After the Validity Test

\begin{tabular}{|c|c|c|c|}
\hline \multirow{2}{*}{$\begin{array}{c}\text { Indicators of } \\
\text { Academic } \\
\text { Stress }\end{array}$} & \multicolumn{3}{|c|}{ Total Items } \\
\cline { 2 - 4 } & $\begin{array}{c}\text { Before } \\
\text { Validity Test }\end{array}$ & \multicolumn{2}{|c|}{ After Validity Test } \\
\cline { 3 - 4 } & & $\begin{array}{c}\text { Valid (r } \geq \\
\mathbf{0 . 3})\end{array}$ & $\begin{array}{c}\text { Invalid (r }< \\
\mathbf{0 . 3})\end{array}$ \\
\hline Affection & 4 & 4 & - \\
\hline Behavior & 6 & 4 & 2 \\
\hline Physiology & 8 & 8 & - \\
\hline Cognitive & 3 & 3 & - \\
\hline Total & $\mathbf{2 1}$ & $\mathbf{1 9}$ & $\mathbf{2}$ \\
\hline
\end{tabular}

Based on the table above, the scale of academic stress before the validity test amounts to 21 items. There are 2 items that are invalid and must be eliminated from the measuring instrument so that the remaining 19 valid items are ready for use in the study. After the validity test, reliability testing is carried out only on items that are declared valid only.

Scale of Self-Regulated Learning. The scale content of self-regulated learning consists of items in the form of statements prepared by researchers based on the theory of selfregulated learning by Zimmerman [13] which has three dimensions, namely dimensions of metacognition, motivation and behavior. Each of these dimensions has an indicator as described previously. The items in this questionnaire were also made by adjusting the research subject, namely students.

This questionnaire also consists of four choices of answers in each statement which are "really not suitable for me", "not suitable for me", "suitable for me" and "very suitable for me". The next stage is the same as the previous academic stress scale construction, namely the 
validity and reliability tests. Then after passing the validity and reliability tests, the scale is ready to be used in the research. The following is a detailed information on dimensions, indicators and the number of valid and invalid items on the self-regulated learning scale.

Table 2. Number of Items on the Self-Regulated Learning Questionnaire Before \& After Validity Test

\begin{tabular}{|c|c|c|c|c|}
\hline \multirow{3}{*}{ Dimention } & \multirow{3}{*}{ Indicator } & \multicolumn{3}{|c|}{ Total Items } \\
\hline & & \multirow{2}{*}{$\begin{array}{c}\text { Before } \\
\text { Validity } \\
\text { Test }\end{array}$} & \multicolumn{2}{|c|}{$\begin{array}{c}\text { After Validity } \\
\text { Test }\end{array}$} \\
\hline & & & $\begin{array}{c}\text { Valid } \\
(r \geq \\
0.3) \\
\end{array}$ & $\begin{array}{c}\text { Invalid } \\
(\mathbf{r}< \\
\mathbf{0 . 3}) \\
\end{array}$ \\
\hline \multirow{6}{*}{ Metacognitive } & Rehearsal & 4 & 4 & - \\
\hline & Elaboration & 3 & 3 & - \\
\hline & Organizing & 3 & 3 & - \\
\hline & Goal Setting & 3 & 3 & - \\
\hline & $\begin{array}{l}\text { Self- } \\
\text { Evaluating }\end{array}$ & 3 & 2 & 1 \\
\hline & Monitoring & 3 & 3 & - \\
\hline \multirow{3}{*}{ Motivation } & Self-Efficacy & 4 & 4 & - \\
\hline & Task Value & 4 & 4 & - \\
\hline & $\begin{array}{l}\text { Internal } \\
\text { Attribution }\end{array}$ & 3 & 3 & - \\
\hline \multirow{3}{*}{ Behavior } & $\begin{array}{l}\text { Effort } \\
\text { Regulation }\end{array}$ & 3 & 3 & - \\
\hline & $\begin{array}{l}\text { Environment } \\
\text { Structuring }\end{array}$ & 3 & 3 & - \\
\hline & $\begin{array}{l}\text { Help } \\
\text { Seeking }\end{array}$ & 3 & 2 & 1 \\
\hline \multicolumn{2}{|l|}{ Total } & 39 & 37 & 2 \\
\hline
\end{tabular}

The table above illustrates the scale of self- regulated learning before the validity test amounts to 39 items. Then after the validity test there are 2 items that are invalid and must be eliminated from the measuring instrument so that the remaining 37 valid items are ready to be used in the study.

Scale of Tawakal in Learning. The construction of tawakal scale in learning begins with the preparation of items in the form of statements and compiled by researchers based on the book Ta'lim Muta'allim by Syaikh Az-Zarnuji. Tawakal in learning has two dimensions, namely surrender dimension and business dimension, then from these dimensions, indicators are made and statements about tawakal attitudes in learning. These items are also made by adjusting the research subject, namely students. Furthermore, this questionnaire also consists of four choices of answers in each statement namely "really not suitable for me", "not suitable me", "suitable for me" and "very suitable for me". 


\section{Result}

The analysis in this study was carried out by multiple regression analysis. Multiple regression analysis was conducted to see the influence between variables in the study. This is needed to answer the research hypothesis, namely:

1. Self-regulated learning has a significant influence on academic stress on students.

2. Tawakal in learning has a significant influence on academic stress on students.

3. Self-regulated learning and tawakal (trust) in learning simultaneously have a significant effect on academic stress on students.

The independent variables in this study are X1, namely self-regulated learning and variable $\mathrm{X} 2$, namely trust in learning. The dependent variable is the $\mathrm{Y}$ variable that is academic stress on students. Multiple regression analysis is carried out with the help of SPSS 24 statistical data processing application, starting with entering the three variables data. Then linear regression analysis is carried out by entering data on variables X1 and X2 into the independent column (s) and data on variable $\mathrm{Y}$ into the dependent column. The results of this analysis consist of several tables, namely variable entered / removed tables, model summary, ANOVA and coefficients. However, in this study only two tables will be able to answer the hypotheses in the study, namely coefficients and ANOVA tables. Exposure to the results of hypothesis testing is divided into test hypotheses 1 and 2 and hypothesis 3 test.

\section{1 1st and 2nd Hypotheses Test Analysis}

Before reading the results of the analysis of hypotheses 1 and 2, the criteria for testing the multiple regression analysis are:

If the value is Sig. smaller than $0.05(\mathrm{p}<0.05)$, then the hypothesis is accepted.

If the value is Sig. greater than 0.05 ( $>>0.05)$, the hypothesis is rejected.

Furthermore, the results of first and second hypotheses testing can be seen in the coefficient table below:

Table 3. Hypothesis 1 and 2 Tests - Variable Coefficients

\begin{tabular}{|c|c|c|c|c|c|c|}
\hline \multirow{2}{*}{\multicolumn{2}{|c|}{ Model }} & \multicolumn{2}{|c|}{$\begin{array}{c}\text { Unstandard } \\
\text { ized } \\
\text { Coefficient } \\
\end{array}$} & \multirow{2}{*}{$\begin{array}{l}\text { Standardize } \\
\text { d } \\
\text { Coefficient } \\
\begin{array}{c}\text { Bet } \\
\text { a }\end{array} \\
\end{array}$} & \multirow[t]{2}{*}{ t } & \multirow[t]{2}{*}{ Sig. } \\
\hline & & B & $\begin{array}{c}\text { Std. } \\
\text { Erro } \\
\text { r }\end{array}$ & & & \\
\hline \multirow[t]{3}{*}{1} & $\begin{array}{l}\text { (Consta } \\
\text { n } \\
\text { t) }\end{array}$ & 50.046 & 5.080 & & 9.852 & .000 \\
\hline & $\left(\mathrm{X}_{1}\right)$ & 196 & .066 & .354 & 2.983 & .003 \\
\hline & $\left(\mathrm{X}_{2}\right)$ & -.395 & .107 & -.437 & -3.687 & .000 \\
\hline
\end{tabular}

The coefficient table above shows that the Sig. for X1 (self-regulated learning) is 0.003 (p $<0.05)$ which means the first hypothesis is accepted. This means that self-regulated learning has a significant influence on academic stress.

Then for variable X2 (tawakal in learning) shows the value of Sig. equal to 0.000 (p $<0.05$ ) which means the second hypothesis is accepted. This means that tawakal in learning has a significant influence on academic stress. 


\section{2 3rd Hypothesis Test Analysis}

By using multiple regression analysis, the results of the 3rd hypothesis test analysis can be seen in the ANOVA table below:

Table 4. 3rd Hypothesis Test Analysis - ANOVA

\begin{tabular}{|c|c|c|c|c|c|c|}
\hline \multicolumn{7}{|c|}{ ANOVA $^{\mathrm{a}}$} \\
\hline \multicolumn{2}{|c|}{ Model } & $\begin{array}{l}\text { Sum of } \\
\text { Squares }\end{array}$ & df & $\begin{array}{l}\text { Mean } \\
\text { Square }\end{array}$ & $\mathbf{F}$ & Sig. \\
\hline \multirow{3}{*}{1} & Regression & 898.798 & 2 & 449.399 & 6.857 & $.001^{b}$ \\
\hline & Residual & 9633.895 & 147 & 65.537 & & \\
\hline & Total & 10532.693 & 149 & & & \\
\hline \multicolumn{7}{|c|}{ a. Dependent Variable: Y } \\
\hline \multicolumn{7}{|c|}{ b. Predictors: (Constant), $X_{1}, X_{2}$} \\
\hline
\end{tabular}

The above ANOVA table shows the results of the third hypothesis test, self-regulated learning and trust in learning simultaneously have a significant effect on academic stress on students. To prove this hypothesis, the ANOVA table can be seen in the column number Sig. that is $0.001(\mathrm{p}<0.05)$ which indicates that the third hypothesis is accepted. This means that the variables of self-regulated learning and tawakal (trust) in learning simultaneously have a significant effect on academic stress on students.

\section{3 Conclusion}

The test results of multiple regression analysis show that the first hypothesis about the effect of self-regulated learning on academic stress on students is accepted (see table 3). Selfregulated learning has been shown to have a significant influence on academic stress in students. Self- regulated learning in some previous studies proved to have an influence in the form of a negative correlation to academic stress, that is if self- regulated learning increases then academic stress will decrease. Vice versa, if self-regulated learning decreases, academic stress will increase [3].

Then the results of the multiple regression analysis on the second hypothesis showed that learning in proven proved to have a significant effect on academic stress on students. Researchers until now have not found a similar study regarding tawakal in learning and its effect on academic stress. Regarding the connection of tawakal in learning towards academic stress, it is proven that the two has negative correlation.

Similar to the correlation between self-regulated learning and academic stress in the first hypothesis, tawakal learning also has a negative correlation with academic stress. What distinguishes these two variables (self-regulated learning and trust in learning) is the dimension of surrender to God which is only on the scale of trust in learning. As previously explained, understanding tawakal does not only surrender to Allah, but the effort to achieve goals is also the main core of tawakal. In this study, the effort indicators on the scale of trust in learning have similarities with indicators in the scale of self- regulated learning.

Furthermore, the results of the analysis of the third hypothesis test also showed that the third hypothesis in this study was received, namely self- regulated learning and learning in provenance simultaneously had an influence on academic stress in students (see table 4). 
Other studies related to the effect of self-regulated learning and learning in learning about academic stress in students hasn'tv been found by researchers.

Acknowledgements. This research was supported by Hibah Publikasi Internasional Terindeks Untuk Tugas Akhir Mahasiswa Universitas Indonesia.

\section{References}

[1] Association, A. C. H. (2016). American College Health Association-National College Health Assessment II: Reference Group Undergraduates Executive Summary Fall 2015. Retrieved from http://www.achancha.org/docs/NCHAII_FALL_2015_UNDERGRADUATE_REFERENCE_GROUP_EXECUT I VE_SUMMARY.pdf

[2] Zimmerman, B. J., \& Martinez-Pons, M. (1988). Construct validation of a strategy model of student self-regulated learning. Journal of Educational Psychology, 80(3), 284-290. https://doi.org/10.1037/0022-0663.80.3.284

[3] Trevisani, C. (2015). A Correlational Study of Self- Regulated Learning, Stress and Mindfulness In Undergraduate Students.

[4] Cross, D. R., \& Paris, S. G. (1988). Developmental and instructional analyses of children's metacognition and reading comprehension. Journal of Educational Psychology, 80(2), 131-142. https://doi.org/10.1037/0022-0663.80.2.131 [18] Az-Zabidi, M. (2000). Taj Al-'Arus min Jawahiril Qamus - Juz 31. In Taj Al-'Arus min Jawahiril Qamus (pp. 96-100). Kuwait: KFAS (Kuwait Foundation for the Advancement of Science).

[5] Laura Jones (2005). What Does Spirituality in Education Mean?. Journal of College and Character, 6:7, DOI: 10.2202/1940-1639.1485

[6] Nasional, U. S. P. (2003). Undang-undang sistem pendidikan nasional. Indonesia.

[7] Husnar, A. Z., Saniah, S., \& Nashori, F. (2017). Harapan, Tawakal, dan Stres Akademik. Psikohumaniora, 2, 94-105.

[8] Al Baqi, M. F. A. (1927). Al Mu’jam al Mufahras li Alfaz il Quran il Kareem. Kairo: Dar AlHadits.

[9] Katsir, I. (2003). Tafsir Ibnu Katsir (terjemah). Bogor: Pustaka Imam Syafi'i.

[10] Al-jauziyah, I. Q. (1998). Madarijus Salikin (Pendakian Menuju Allah). Pustaka Al-Kautsar.

[11] Sartika, A., \& Kurniawan, I. N. (2015). Skala Tawakal Kepada Allah: Pengembangan Ukuran-Ukuran Psikologis Surrender To God Dalam Perspektif Islam. Psikologika: Jurnal Pemikiran Dan Penelitian Psikologi. https://doi.org/10.20885/psikologika.vol20.iss2.art3

[12] Lakaev, N. (2009). Validation of an Australian academic stress questionnaire. Australian Journal of Guidance and Counselling, 19(1), 56-70. https://doi.org/10.1375/ajgc.19.1.56

[13] Zimmerman, B. J. (1989). A Social Cognitive View of Self-Regulated Academic Learning By : Barry J . Zimmerman A Definition of Self-Regulated Learning EBSCOhost Page 2 of 23 A View of Student Self- Regulated Academic Learning Social Cognitive Assumptions. Journal of Education Psychology, 81(3), 1-23.

[14] Az-Zarnuji, S. (2009). Ta'lim Muta'allim Terjemah. Surabaya: Mutiara Ilmu.

[15] Lazarus, R. S., \& Folkman, S. (1984). Stress, Appraisal, and Coping. https://doi.org/10.1037//0033- 2909.116.2.340

[16] Lazarus, R. S. (1982). Thoughts on the relation between emotion and cognition. American Psychologist, 37(9), 1019-1024. https://doi.org/10.1037/0003-066X.37.9.1019

[17] Kohn, J. P., \& Frazer, G. H. (1986). An Academic Stress Scale: Identification and Rated Importance of Academic Stressors. Psychological Reports, 59, 415-426.

[18] Santrock, J.W. (2004) Educational Psychology. 2nd Edition, McGraw-Hill, New York.

[19] Manzhur, I. (1955). Lisanul Arab - In حرف الامLisanul Arab (pp. 734-736). Beirut: Dar A1 Sadir. 
[20] Az-zabidi, M. (2000). Taj Al-‘Arus min Jawarihil Qamus (pp. 96-100). Kuwait: KFAS (Kuwait Foundation for the Advancement of Science).

[21] Al-Munajjid, M. S. (2009). At-Tawakkal. ZAD Group

[22] Al-Ghazali, A. H. (1963). Ihya Ulumiddin (terjemah). Jakarta.

[23] Shihab, N., \& Shihab, M. Q. (2018). Shihab \& Shihab eps. 26 - Tawakal - YouTube. Retrieved July 8, 2018, from https://www.youtube.com/watch?v=Z2UYbKV_T1c 